\title{
BEYOND LITHIUM-ION: LITHIUM- SULPHUR BATTERIES FOR SPACE?
}

\author{
Maria Nestoridi ${ }^{(1)}$, Henri Barde ${ }^{(1)}$ \\ (1) ESA/ESTEC, Keplerlaan 1, 2200 AG Noordwijk - The Netherlands, \\ Maria.Nestoridi@esa.int,Henri.Barde@esa.int
}

\begin{abstract}
Lithium-ion (Li-ion) batteries are established as the state of the art [1] rechargeable batteries for terrestrial and space applications today since the launch of Proba 1 satellite in 2001. [2]

At the moment there is strong interest by all stakeholders related or influenced by the battery markets on two systems: The rechargeable $\mathrm{Li}$-air $\left(\mathrm{Li}-\mathrm{O}_{2}\right)$ and $\mathrm{Li}-\mathrm{Sulfur}$ (Li-S) batteries. There have been many studies on both technologies during the past decades but since major challenges are still to be overcome, none of the two technologies has been yet commercialized.

Li-S is believed to reach mass commercialization towards the end of the decade whereas $\mathrm{Li}-\mathrm{O}_{2}$ is expected to be available after 2030. Therefore, discussion to follow hereby will focus on Li-S.

Li-S cells are regarded as one of the most promising systems for next generation batteries due to their high theoretical capacity, the abundant and low cost sulfur resources and lithium-ion comparable cathode production techniques. [RD3] If Li-S batteries were to be successfully developed and reach their theoretical maximum, batteries over six times lighter than the conventional lithium-ion ones, would be available. [RD4]

Sion Power in the US and OXIS Energy Ltd. in Europe are the major companies producing Li-S cells.

Prototype Cells were procured from Oxis Energy, UK and characterisation tests were performed at ESAESTEC Battery Life Test Facility in Noordwijk, Netherlands. The results are presented here, mainly in order to enhance basic understanding on existing technology in Europe and show relevant trends.

Consequences at power system level, if this technology was to be adopted for satellite applications, are also addressed in this paper.
\end{abstract}

\section{OXIS SPECIFICATIONS FOR ULTRA-LIGHT CELLS}

The OXIS Cell Specifications as per OXIS technical manual for the Ultra-light prototype cells are provided in Tab. 1. [5]

Six Ultralight prototype cells were procured and tested at ESA-ESTEC Battery Life Test Facility.

\begin{tabular}{|c|c|}
\hline Part Number & POA0084 \\
\hline Nominal Voltage & $2.1 \mathrm{~V}$ \\
\hline $\begin{array}{l}\text { Cell Capacity, } \\
\text { discharged at: } \\
0.2 \mathrm{C} \& 20^{\circ} \mathrm{C} \text { to } 1.9 \mathrm{~V}\end{array}$ & 6.5 Ah typical \\
\hline 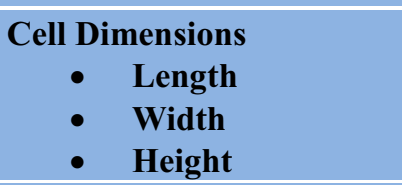 & $\begin{array}{l}146 \mathrm{~mm} \\
76 \mathrm{~mm} \\
7 \mathrm{~mm}\end{array}$ \\
\hline $\begin{array}{c}\text { Tab Dimensions } \\
\text { - } \quad \text { Length } \\
\text { - Width }\end{array}$ & $\begin{array}{l}25 \mathrm{~mm} \\
20 \mathrm{~mm}\end{array}$ \\
\hline Cell Mass & $55 \mathrm{~g}$ \\
\hline Specific Energy & 248Wh/kg \\
\hline Volumetric Energy & $\begin{array}{c}180 \mathrm{Wh} / \mathrm{L} \\
\text { without tabs }\end{array}$ \\
\hline $\begin{array}{l}\text { Operating Temperature } \\
\text { - } \quad \text { Discharge } \\
\text { Charge } \\
\text { - Storage }\end{array}$ & $\begin{array}{l}-20^{\circ} \mathrm{C} \text { to }+30^{\circ} \mathrm{C} \\
\text { Not tested, } \\
\text { recommend } \\
20^{\circ} \mathrm{C} \\
\text { Not tested, } \\
\text { recommend } 10- \\
30^{\circ} \mathrm{C}\end{array}$ \\
\hline Charging Method & $\begin{array}{l}\text { Constant current } \\
\text { only, with time } \\
\text { limit and } \\
\text { voltage limit cut } \\
\text { offs }\end{array}$ \\
\hline Charging Current & $650 \mathrm{~mA}(\mathrm{C} / 10)$ \\
\hline Charging Time Limit & $\begin{array}{l}10 \text { hours from } \\
0 \% \text { State of } \\
\text { Charge }\end{array}$ \\
\hline Charge Voltage Limit & $2.6 \mathrm{~V}$ \\
\hline $\begin{array}{l}\text { Discharge Rates } \\
-\quad \text { Constant } \\
\text { Current }\end{array}$ & $\begin{array}{l}4.9 \mathrm{~A}(0.75 \mathrm{C}) \text { is } \\
\text { maximum tested }\end{array}$ \\
\hline Discharge Voltage Limit & $1.9 \mathrm{~V}$ \\
\hline $\begin{array}{l}\text { Cycle Life, at } 0.1 \mathrm{C} \\
\text { charge, } 0.2 \mathrm{C} \\
\text { discharge } \\
\text { and } 20^{\circ} \mathrm{C}\end{array}$ & $\begin{array}{l}39 \text { cycles to } \\
80 \% \text { Beginning } \\
\text { of Life }\end{array}$ \\
\hline
\end{tabular}

Table 1. OXIS Ultra-Light Cells Specifications. [5] 
An important remark at this stage is that due to the limited number of cells more than one test was performed with each cell. Therefore considering that those cells are prototypes and that each cell has a considerable testing history that would naturally influence aging and capacity fading, the actual numbers of capacity are not to be considered, unless it's stated otherwise. The general trends and characteristics of this technology is where the reader's attention is meant to be drawn in this paper.

\section{TEST SET UP at ESTEC}

The cells were first placed inside an abuse chamber due to their prototype nature. The abuse chamber itself was flushed with nitrogen for safety reasons and was sited inside an environmental chamber so that the temperature could be adjusted as needed.

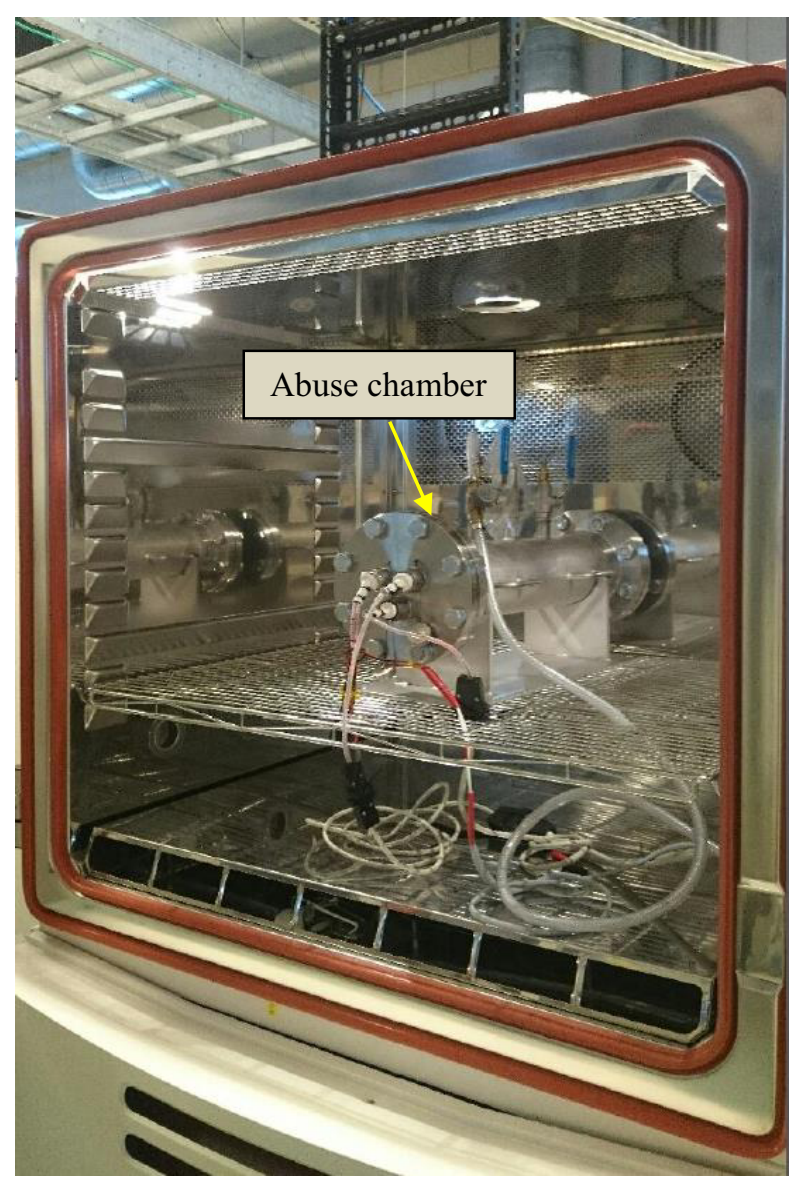

Figure 1. Test Set-up at ESA-ESTEC Battery Life Test Facility

\section{LI-ION VS LI-S}

The OXIS Lithium Sulphur battery cells tested typically operate between 2.6 and $1.9 \mathrm{~V}$ in contrast to Lithium-ion cells that operate between 4.2 and $2.7 \mathrm{~V}$.

In Fig. 2 the typical voltage curves and temperature evolution for common Li-ion cells are presented for comparison with relevant data from OXIS Li-S cells tests. The major difference in the voltage curves is that the Li-S discharge curve comprises of two plateaus. This is a known characteristic of the Li-S cell which is believed to be attributed to a series of structural and morphological changes [6] during the charge/discharge process involving the formation of soluble lithium polysulfides $\mathrm{Li}_{2} \mathrm{~S}_{\mathrm{x}}\left(1^{\text {st }}\right.$ plateau $)$ and insoluble sulfides $\mathrm{Li}_{2} \mathrm{~S}_{2} / \mathrm{Li}_{2} \mathrm{~S}$ (2 ${ }^{\text {nd }}$ plateau) in the liquid electrolyte.

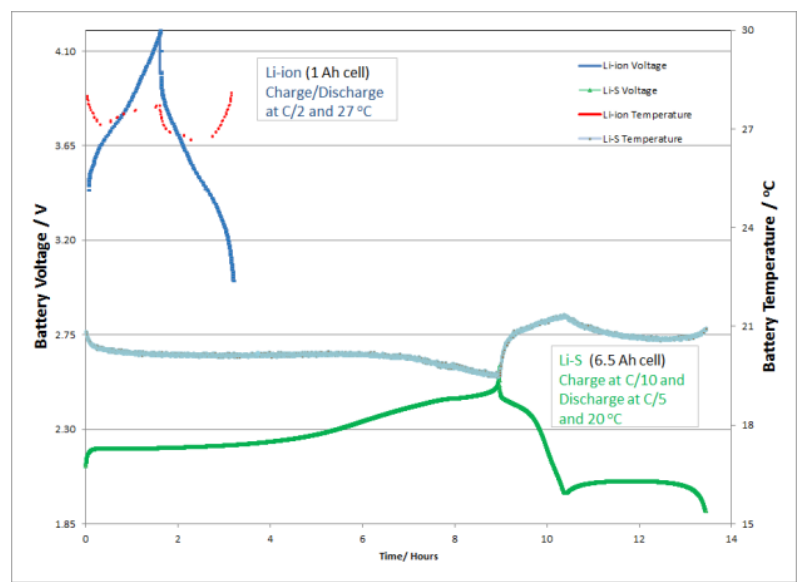

Figure 2. Li-ion vs Li-S Voltage Curves and Temperature during charge and discharge

\section{TEST RESULTS}

The results from the tests conducted with OXIS UltraLight Li-S cells at the ESA-ESTEC Battery Life Test Facility are presented in this section.

In Fig. 3 the voltage curve and relevant capacity obtained with a fresh cell during charge at $\mathrm{C} / 10$ and $20^{\circ} \mathrm{C}$ are presented. Slightly lower capacity value than the one defined at OXIS datasheet is obtained. This is attributed to the fact that data in current OXIS datasheet correspond to tests performed at $30{ }^{\circ} \mathrm{C}$ whereas tests by ESA were conducted at $20^{\circ} \mathrm{C}$.

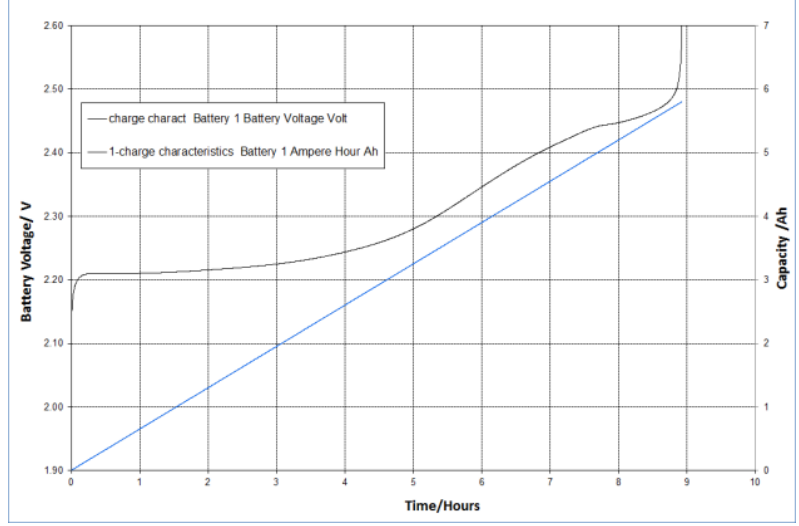

Figure 3. Charge Characteristics of Oxis Ultra-Light Li-S cell at C/10 and $20^{\circ} \mathrm{C}$ 
In Fig. 4 the voltage curves vs capacity for discharge from 2.6 V to $1.9 \mathrm{~V}$ and $20{ }^{\circ} \mathrm{C}$ are presented for different $\mathrm{C}$ rates, ranging from $\mathrm{C}$ to $0.1 \mathrm{C}$. It can be seen that for $\mathrm{C}$, $0.25 \mathrm{C}$ and $0.5 \mathrm{C}$ only the first voltage plateau is exhibited during discharge. For $0.3 \mathrm{C}, 0.2 \mathrm{C}$ and $0.1 \mathrm{C}$ the second voltage plateau can also be seen and the capacity obtained is significantly greater than for the higher rates.

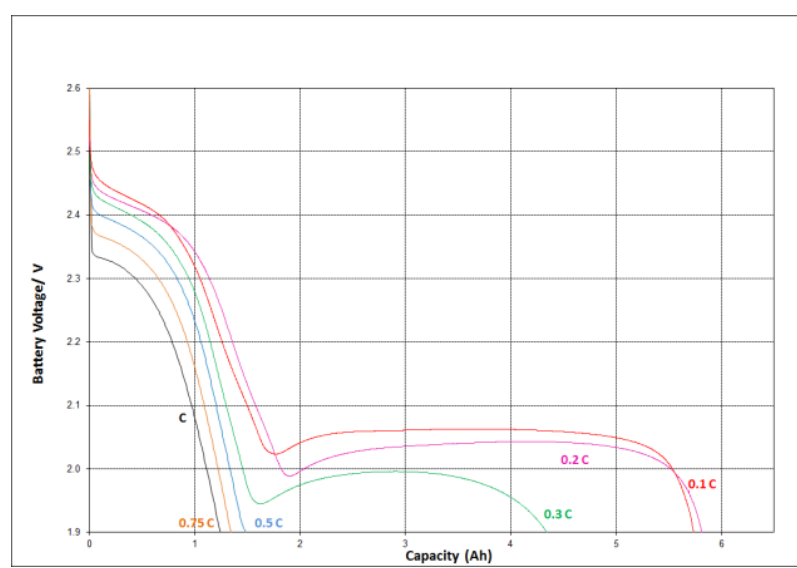

Figure 4. Discharge Characteristics of Oxis UltraLight Li-S cells at $20^{\circ} \mathrm{C}$ and different $\mathrm{C}$-rates

In Fig.5 the voltage curves for discharges at $\mathrm{C} / 5$ for temperature values ranging from $-20{ }^{\circ} \mathrm{C}$ to $+20{ }^{\circ} \mathrm{C}$ are shown. It is evident that the End of Discharge cut-off voltage for tests conducted at temperatures below $20{ }^{\circ} \mathrm{C}$ is lower than the standard $1.9 \mathrm{~V}$ value. This was done in order to compensate for the low temperature slow kinetics and allow the full discharge reaction to occur in order to maximise the cell capacity obtained. For $-20{ }^{\circ} \mathrm{C}$ no capacity is virtually obtained. The cell can operate at temperatures from $-10{ }^{\circ} \mathrm{C}$, however the performance is significantly decreased below $0{ }^{\circ} \mathrm{C}$.

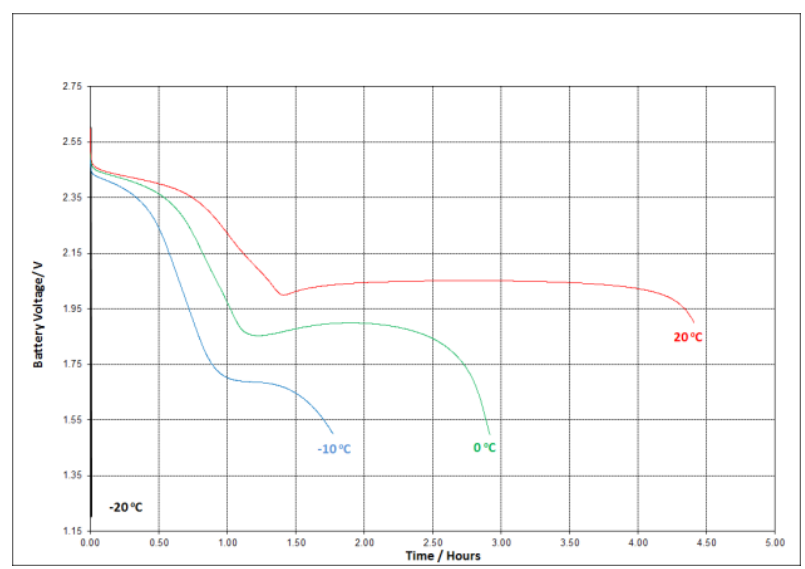

Figure 5. Discharge Characteristics of Oxis UltraLight Li-S cells at C/5 and different temperatures

In Fig. 6 the Internal Resistance of OXIS Ultra-Light Li$\mathrm{S}$ cells at different temperatures and different DoDs is presented. From these data, a significant increase in internal resistance is shown to occur, for all DoDs, for temperature values lower than $0{ }^{\circ} \mathrm{C}$.

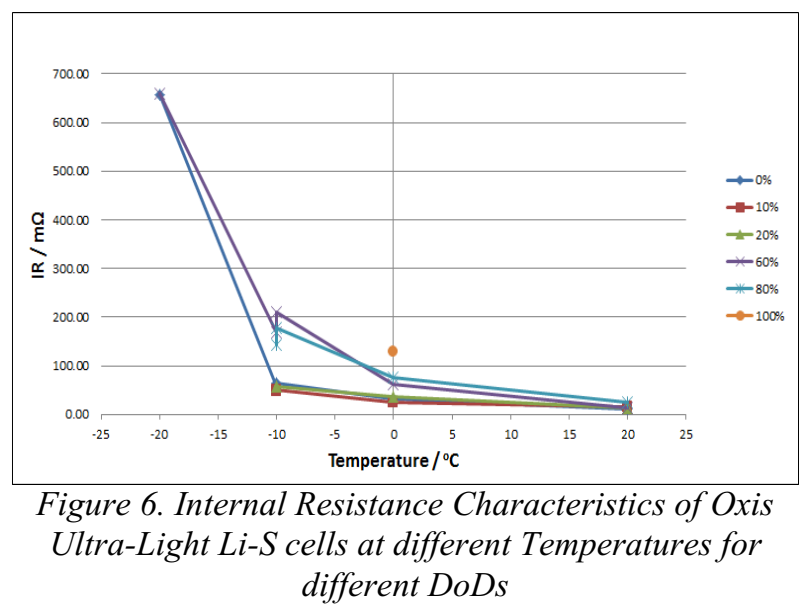

In Fig. 7 internal resistance data for different $\mathrm{C}$-rates and DoDs are presented. The C-rate does not seem to have a significant influence in internal resistance for a specific DoD value. The internal resistance seems to exhibit minimum values mostly at $10 \%$ or $20 \%$ DoDs and it reaches a maximum value at higher DoDs.

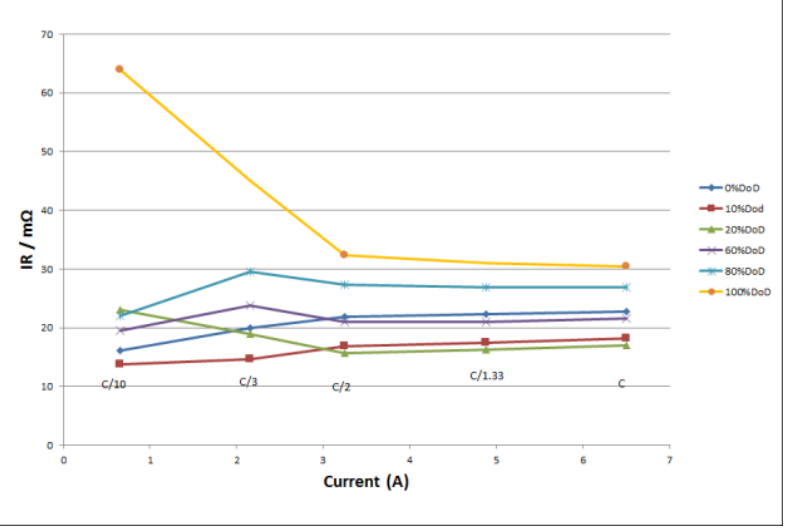

Figure 7. Impact of C-rate in IR Internal Resistance Characteristics of Oxis Ultra-Light Li-S cells at different Temperatures for different DoDs

In Fig. 8 the Internal resistance values, for a discharge at $\mathrm{C} / 5$ at $20^{\circ} \mathrm{C}$, are marked along with the relevant DoDs on the voltage curve of an Oxis Ultra-Light Li-S cell. As shown from data in Fig.7 previously, here the internal resistance at the beginning of the discharge reaches a minimum value, i.e. at the first voltage plateau, and a maximum one at the end of the discharge. 


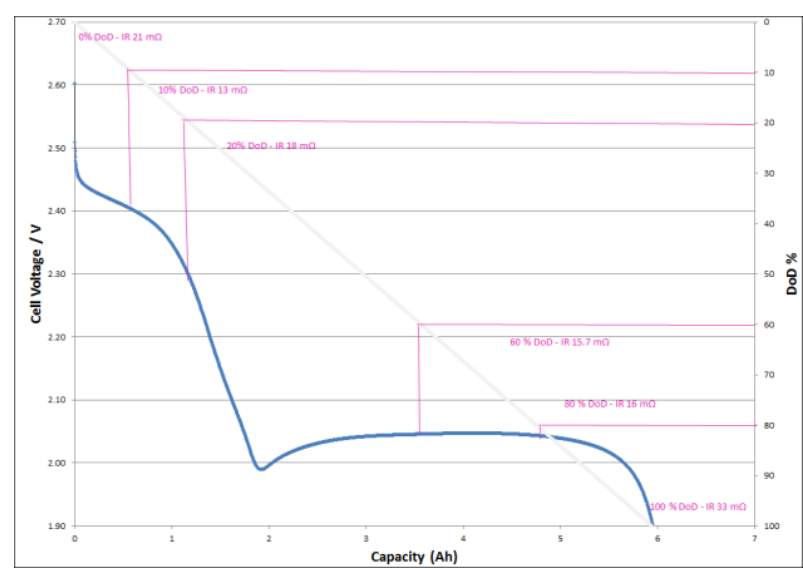

Figure 8. Impact of DoD in Internal Resistance Characteristics of Oxis Ultra-Light Li-S cells at $20^{\circ} \mathrm{C}$

In Fig.9 specific energy data vs cycle number are presented for a number of cycling regimes carried out with OXIS Lithium Sulphur cells. The initial specific energy and its relevant progression with cycling is significantly higher at $20{ }^{\circ} \mathrm{C}$ compared to $0^{\circ} \mathrm{C}$ when cycling at $100 \%$ DoD and $\mathrm{C} / 10$ charge and $\mathrm{C} / 5$ discharge rates. Cycling at the latter $\mathrm{C}$-rates but at lower DoD proved to improve cell cycle life. Cycling at $20 \% \mathrm{DoD}$ and $20^{\circ} \mathrm{C}$ seems to result in better cyclability, compared to higher DoDs, even when cycling was conducted at faster rates, i.e. $\mathrm{C} / 3$ charge and $\mathrm{C} / 2$ discharge. Cycling that was conducted at the latter rates and $20 \% \mathrm{DoD}$ but at $0{ }^{\circ} \mathrm{C}$, despite stability in cycling, exhibited lower specific energy values than the same test conducted at $20{ }^{\circ} \mathrm{C}$.

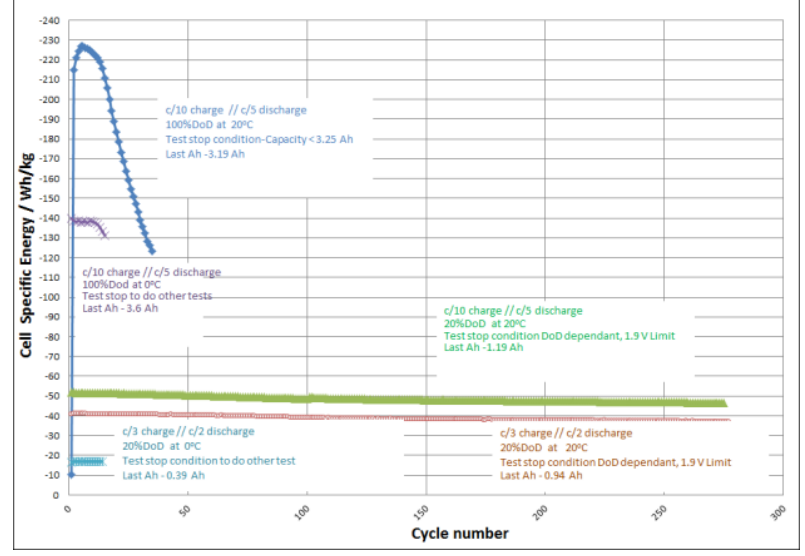

Figure 9. Cycling Tests Synthesis

\section{ASSESMENT vS SPACE REQUIREMENTS}

All test data presented in this paper show that the DoD plays a significant role in the $\mathrm{Li}-\mathrm{S}$ cell cyclability. According to existing data, Li-S cells could be considered as a potential energy storage for satellites, for LEO missions, where the spacecraft battery is discharged at a low DoD. In contrast, further work, aiming to improve stability of the cells' performance with cycling at high DoDs, is required in order to make Li-S battery technology a good candidate for GEO missions.

On the rate capability side, when the cells are discharged at rates equal or higher to $0.5 \mathrm{C}$ the second discharge voltage plateau is not reached and therefore the obtained capacity is limited, implying that not all discharge reactions are occurring at high rates. For LEO and GEO applications, the battery needs to be capable to perform discharge at $\sim \mathrm{C} / 2$ rates. Therefore, if Li-S battery technology was to be considered for satellite applications the relevant discharge rate capability should be improved.

The data presented in this paper show that the temperature has also a great impact on the specific energy obtained from these Li-S cells. Poor specific energy values were obtained when the cell was cycled at $0{ }^{\circ} \mathrm{C}$. Nowadays the operational temperature window for Liion satellite batteries is commonly between 0 and $30^{\circ} \mathrm{C}$. It may be that this window should be pushed upward, provided that a higher operating temperature does not adversely affect the ageing.

\section{IMPACT ON EPS DESIGN}

It may appear premature to try anticipating what could be the impact of the use of Li-S batteries onto spacecraft Electrical Power System (EPS) but such a reflection, though, is not worthless, even if the technology is still at an early stage of development.

The first impact would be on the battery itself: the available capacities, which, in a context of spin-in, could range from very small (portable appliances) to quite large (Electric vehicle of power grid levelling), will have an influence on the series/parallel assembly, provided that the electrical properties allow paralleling at cell level. The need for balancing is also an important aspect. This depends on the capability of the technology to accept a moderate level of overcharging without degradation of performance, as was the case for the alkaline $\mathrm{NiCd}$ and $\mathrm{NiH}_{2}$. In this case, a small excess capacity return after a discharge allows bringing back all individual cells to their maximum State of Charge. A dedicated test has been performed on one of the cells available at ESA at $\mathrm{C} / 100$ overcharging rate for a duration of 27 hours, followed by a 11 hours open circuit and a discharge attempt.

The Fig. 10 shows the cell voltage and temperature as a function of time.

The very first outcome is that, following this $0.27 \mathrm{C}$ overcharging, the cell was no longer able to deliver any energy. The second result, of little use in view of the previous one, though, is that even at a charging rate as low as $\mathrm{C} / 100$, no stabilisation is achieved, i.e. the simple balancing approach mentioned above cannot be relied on and a dedicated functionality would have to be implemented. On top of this, the End of Charge will have to be managed properly to avoid damaging the cell. As 
mentioned above, the current results are subject to the cell test history and consequent aging; further tests are therefore required to characterise $\mathrm{Li}-\mathrm{S}$ cells throughout their lifetime for the missions of interest.

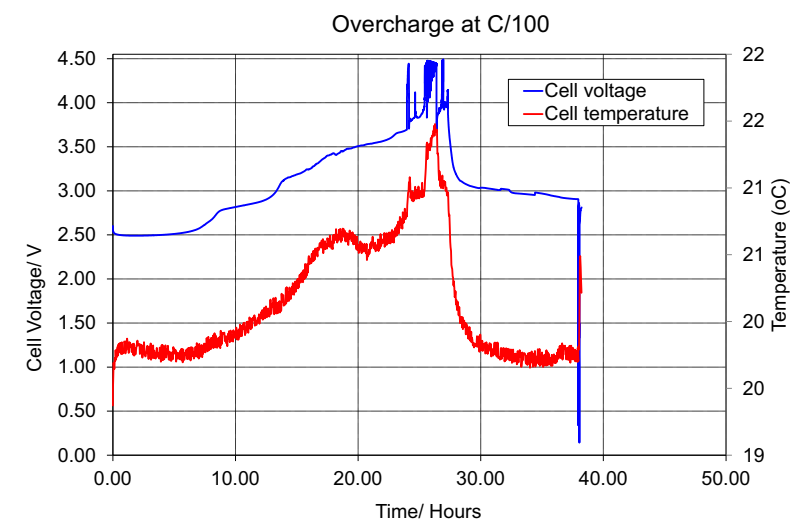

Figure 10. Cell voltage and temperature during low rate overcharge test

At EPS level, the first striking feature of Li-S is the fact that the voltage versus discharged capacity curve is not monotonic. The immediate consequence is that the battery voltage will probably not be usable as a capacity indicator, requiring some sort of Ampere.hour meter to estimate the actual State of Charge (SoC). This has been routinely done in the past: the battery management of the METOP and ENVISAT ESA spacecraft used that approach but their NiCd technology accepted easily a full discharge. Things are different in case the battery needs to be disconnected to avoid irrecoverable damages. This may result from a situation where the Ah meter, usually a software process, is no longer operating. Therefore, a voltage threshold appears safer but it needs to be selected carefully. Looking at Fig.4, at a typical discharge rate of $\mathrm{C} / 3$, the voltage difference between the end of the first plateau and the full discharge is quite small, introducing the risk of an unwanted disconnection.

A positive feature, on the opposite, is the charge management technique, which calls for a complete stop of the charge under constant (or available) current upon reaching the cut-off voltage. The absence of taper means that, for Low Earth Orbit (LEO) missions, the solar array would be better used, since there is no need to shunt available power to limit the battery current. This might have to be mitigated by the coulombic round trip efficiency, though, which has been difficult to assess during the various tests, the relatively quick decay of available capacity introducing a bias difficult to evaluate. It does not seem, though, that it is very far from unity. The round trip energetic efficiency was found close to 90 $\%$, which is a reasonable value, given similar uncertainty. Altogether it can be expected that the introduction of $\mathrm{Li}-\mathrm{S}$ in EPS would involve significant changes, possibly of a larger magnitude than these met when transitioning from alkaline technologies to $\mathrm{Li}$-ion. This would be the price to pay for accessing what would be a significantly better performing technology

\section{CONCLUSION}

The maturity of Li-S batteries, as of today, is not yet sufficient to consider this technology other than a potential satellite energy storage mean. Nevertheless, taking into account the present status and the theoretical capabilities of Li-S electrochemical system, potentially yielding specific energy performances six times better than Li-ion, Li-S is undoubtedly an interesting battery technology to work on, as a preparation for the future energy storage on-board satellites.

\section{REFERENCES}

1. Defer, M., Du Peyrat, D., Prévot, D., Borthomieu, Y. (2008) Qualification of high specific energy liion cell VES180SA, 8th European Space Power Conference, ESA-SP Vol. 661

2. Genc, Z. D., Thwaite. C. (2011) Proba-1 and Mars Express: An ABSL Lithium-ion Legacy, 9th European Space Power Conference, ESA SP Vol. 690

3. Hagen, M., Dörfler, S., Fanz, P., Berger, T. ., Speck, R., Tübke, J., Althues, H., Hoffmann, M.J., Scherr, C., Kaskel. S. (2013) Development and costs calculation of lithium-sulfur cells with high sulfur load and binder free electrodes, Journal of Power Sources 224, 260-268.

4. Bruce, P.G., Freunberger, S.A.,. Hardwick L., Tarascon. J. M. (2012) $\mathrm{Li}-\mathrm{O}_{2}$ and $\mathrm{Li}-\mathrm{S}$ batteries with high energy storage, Nature Materials 11, 1929.

5. Oxis Technical Manual, Ultra-Light cells 2015.

6. Manthiram, A., Fu, Y., Su., Y. S. (2012) Challenges and Prospects of Lithium-Sulfur Batteries. Accounts of Chemical Research, 2013 May 21;46(5):1125-34 